
Informations

une revue Gallia

Rhône-Alpes | 2007

\title{
Le Teil
}

Contournement RN 86 Le Teil-Rochemaure

André Rebiscoul

\section{(2) OpenEdition}

Édition électronique

URL : http://journals.openedition.org/adlfi/7136

ISSN : 2114-0502

Éditeur

Ministère de la culture

Référence électronique

André Rebiscoul, «Le Teil », ADLFI. Archéologie de la France - Informations [En ligne], Rhône-Alpes, mis en ligne le 01 mars 2007, consulté le 03 mai 2019. URL : http://journals.openedition.org/adlfi/7136

Ce document a été généré automatiquement le 3 mai 2019.

(c) Ministère de la Culture et de la Communication, CNRS 


\section{Le Teil}

\section{Contournement RN 86 Le Teil-Rochemaure}

\section{André Rebiscoul}

Date de l'opération : 2007 (SD)

1 Ce contournement entre le Teil et Rochemaure a fait l'objet d'un diagnostic archéologique au mois de décembre 2006.

2 Ce projet couvre une distance de 4,5 $\mathrm{km}$ de long et se trouve en limite ouest actuelle du lit du Rhône. Tous les sondages n'ont pas permis d'atteindre la terrasse qui se trouve à plus de $6 \mathrm{~m}$ de profondeur et les quelques fragments de céramique qui ont été recueillis sont modernes. La construction récente du canal latéral au Rhône a profondément modifié ce contexte et il apparaît, après projection du projet routier sur fond Cassini, que celui-ci occupe l'ancien lit majeur du Rhône. Les sondages confirment la modernité de ces dépôts.

3 REBISCOUL André

\section{INDEX}

Index chronologique : ép. contemporaine

Index géographique : Rhône-Alpes, Ardèche (07), Teil

operation Sondage (SD) 


\section{AUTEURS}

ANDRÉ REBISCOUL

INRAP 